\title{
People's Intention to Visit Tourist Destinations during the Covid-19 Pandemic in Surabaya
}

\author{
Umi Faricha Bascha a 1 iD, Adiana Mutamsari Witaningrum a iD, Dwi Setiani Sumardiko a iD, \\ Dian Yuli Reindrawati ${ }^{a}$
}

${ }^{a}$ Universitas Airlangga, Surabaya, Indonesia

\section{APA Citation:}

Bascha, U. F., Witaningrum, A. M., Sumardiko, D. S., \& Reindrawati, D. Y. (2021). People's intention to visit tourist destinations during the covid-19 pandemic in Surabaya. TIJAB (The International Journal of Applied Business), 5(1), 60-70.

Submission Date: 12/02/2021

Acceptance Date: 26/04/2021

\begin{abstract}
The Covid-19 pandemic has affected tourism sectors, for example, resulting in social restrictions and travel restrictions. The declining number of tourists visiting tourist destinations has impacted cities for tourists including Surabaya. This paper aimed to analyze the Surabaya people's desire to make a leisure trip during the pandemic. A total of 121 questionnaires from 500 distributed ones which met the criteria were analyzed. The findings showed that the majority of Surabaya's residents had no intention of traveling during the pandemic as the Surabaya government implemented many travel restrictions, including large-scale social restrictions (LSSR) several times. The travel restrictions reduced the chance for traveling out of and into the Surabaya areas. The results of the questionnaires showed that green tourism would be the most chosen tourist destination by the respondents to visit if the pandemic calmed down. Culinary tours were placed in the second rank, followed by marine tourism and religious tourism. Suggestions for further research are that the government can provide more massive counseling about the importance of maintaining cleanliness. For instance, it needs to promote changing masks regularly and educating the public about the importance of Cleanliness Health Environment and Safety (CHSE) applied by all tourist destinations and other public places.
\end{abstract}

Keywords: tourism; intentions; CHSE

This is an open-access article under the CC BY-NC-SA license.

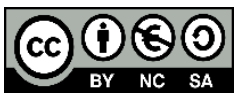

\section{Introduction}

People all over the world have reduced their intention to travel outside since 2020. The Covid-19 outbreak is one of the causes. The virus, which was first discovered in Wuhan in 2019, has rapidly spread throughout the world and caused travel restrictions applied across countries and within cities in the countries. This travel restriction also applies in Indonesia. Large-scale social restrictions (LSSR) have

\footnotetext{
${ }^{1}$ Corresponding author.

E-mail address: umi.f.bascha@vokasi.unair.ac.id
} 
been applied to major cities in Indonesia. The policy on Large-Scale Social Restrictions (LSSR) or Pembatasan Sosial Berskala Besar (PSBB), for the first time, was implemented on April 10, 2020, in Jakarta, Indonesia, followed by several other regions (Ristyawati, 2020). Furthermore, despite the prevailing LSSR, especially concerning the current drastic decline in the economic condition, the government must guarantee and ensure that the lower middle class can meet their needs.

The implementation of the policy has reduced the number of visits to the city of Surabaya. At nineteen regional points in Surabaya, roads were closed on April 5, 2020 (Humas Surabaya, 2020) to reduce community travel, in addition to the government's programs to break the chain of the virus spread. Travel restrictions have been done not only by land but also by air. In the statistical decline in the number of domestic flights, in January 2020 the number of people travelling stood at 6.29 million people, decreasing to 780,000 people taking domestic flights by June 2020 .

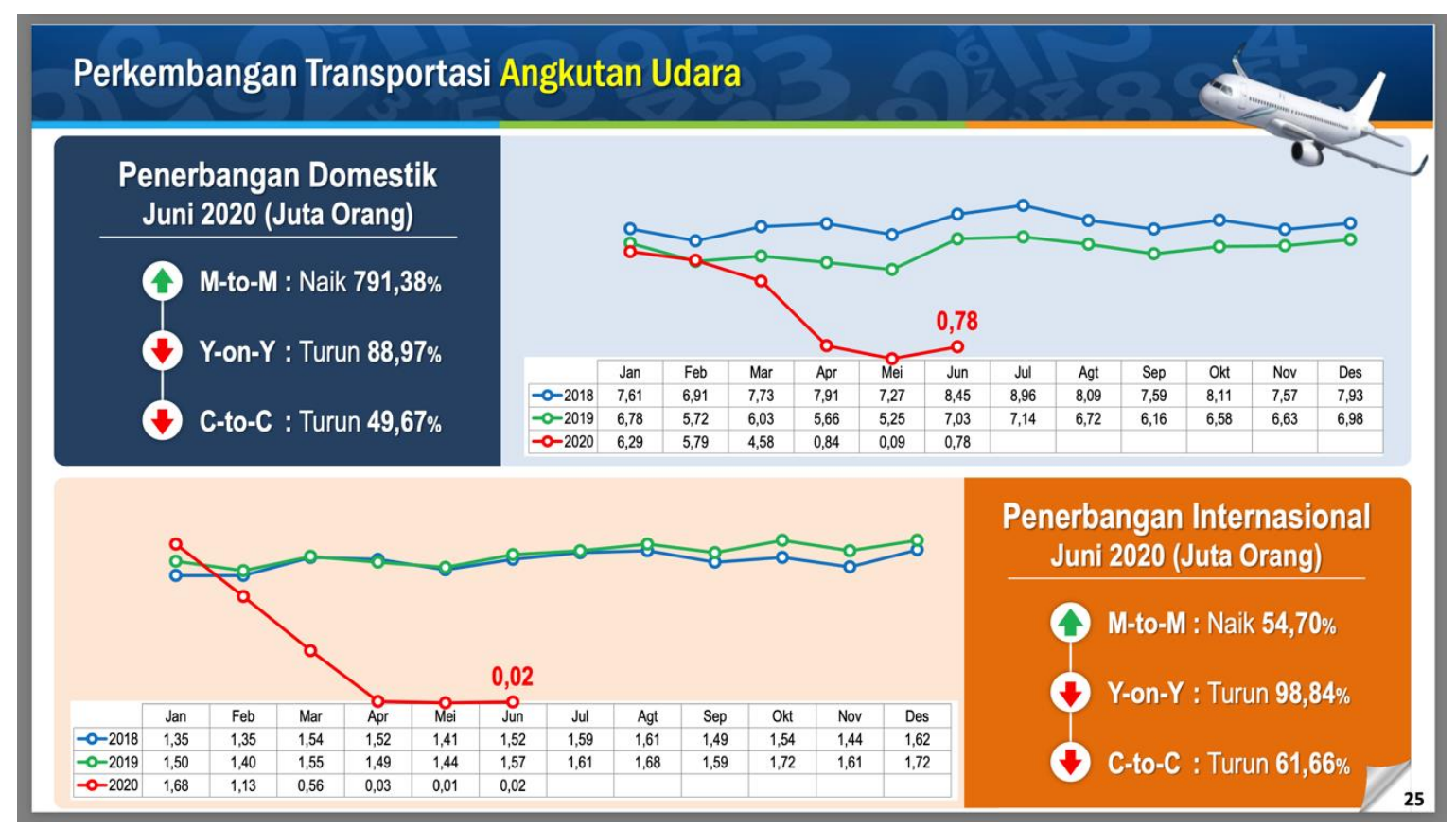

Source: Indonesia's Central Bureau of Statistics in 2020

Figure 1. Table of a domestic and international flight in June 2020

It was reported that several international airlines were canceled until an unprecedented time limit while around 17,000 planes around the world were still parked (BBC, 2020). Travel restrictions around the globe have limited not only international flights but also domestic flights. Domestic and international flight have strict regulations, including the need for an official travel warrant and a valid health certificate, including a rapid test and swab laboratory test result (CNBC, 2020); some of these regulations have made the community cancel several travel plans.

Apart from travel restrictions, the closure of several tourist destinations has also caused people to cancel their tours. A total of 56 tourist attractions in East Java were closed on March 15, 2020 (Travel Kompas, 2020) because such a retriction could decline people's intention to travel. Another reason of implementing that restriction was to surpress the number of foreign tourist arrivals to Surabaya; in March 2020, Statistics Indonesia recorded a decrease of 50.65\% from February of the same year. The first Covid-19 case emerging in Indonesia and several other countries made tourists stay in their respective countries and cancel domestic and international trips. 
From the perspective of tourism research, it has mainly focused on studying how tourists develop their perceived risk and the impacts of the latter on their decision-making processes, future intentions, and segmentation profiles (e.g., Dolnicar, 2005, Aliperti and Cruz, 2019, Araña and León, 2008). Others have also examined how the tourists' perception of crisis management preparedness certification affects their travel intentions (e.g., Pennington-Gray et al., 2014). Such research is essential as risk perceptions are important for predicting future tourism demandx and drafting appropriate recovery strategies (Rittichainuwat \& Chakraborty, 2009). It is also relevant for research to investigate on the trends of tourism during the Covid-19 because of a unanimous call to see and use the pandemic as a transformative opportunity (Mair, 2020). The industry should recover, reimagine, and reform the following standard and economic order (McKinsey, 2020).

Based on the aforementioned issues - travel restrictions and tourist arrivals declining in 2020, the current study aimed to discuss people's intention to travel to tourist destinations during the Covid-19 pandemic.

\section{Literature Review}

\subsection{Travel, Tour and Tourism}

According to Dilek (2018), someone who moves between different geographic locations for any duration and any purpose is a traveler. Travel includes all trips from one place to another and those made to visit a country for leisure, work, study, or who pass through a country without stopping. The word for tourism comes from the Sanskrit word "tourism", which means "travel". This word is associated with the word "travel" in English; therefore, "tourist" also refers to the word "traveler". Tourism is plural and defined as matters related to tourism, which in English is called tourism (Suwena, 2017). Burkart and Medlik (1974, p. 46) defined another classic definition that "a tourism destination is a geographical unit visited by tourists being a self-contained center". Leisure tourism (holiday) predominates in terms of participation and becomes the most important type of tourism (Tureac, 2008). Many leisure tourism is available in big cities, especially those as major economic centers, because of stress accumulated in the dynamic of economic processes.

\subsection{Visiting Intention}

During the Covid-19 pandemic, people tend to less commit outdoor activities and prefer activities at home, as well as delay and even cancel their travel plans. The impact of the pandemic resulted in a decline in hotel room occupancy in the first quarter of 2020. Based on Indonesia's Central Bureau of Statistics in March 2020, the Room Occupancy Rate (ROR) of star hotels in East Java in that month reached $36.81 \%$ or decreased by 15.84 points compared to the previous month. The ROR for 2 (two) star hotels at $42.36 \%$ is the highest compared to other star hotels. Based on PHRI data, the tourism industry has experienced a potential loss of income from around the US \$ 4 billion, equivalent to Rp 60 trillion from January 2020 to April 2020 due to the decline in foreign tourist arrivals during the Covid19 outbreak.

Meanwhile, the hotel sector lost potential revenues of around Rp 30 Trillion from the domestic market. Fewer outdoor activities affect not only tourist destinations and hotels but also restaurants. The restaurant reservations and on-site consumption in March 2020 globally dropped to 100\% compared to the same month in 2019 in different countries (OpenTable, 2020). In March 2020, in Brazil, 68\% fewer people visited restaurants and snack bars (Lo' pez, 2020). Unlike an exclusively economic crisis, in which the decline in consumption is gradual, the crisis caused by COVID-19 is an abrupt drop in revenues (Richter, 2020). 


\subsection{Travel Restriction}

The Covid-19 outbreak in 2019 first hit the city of Wuhan, causing a massive and rapid spread throughout the world. To stop the spread of the covid-19, the government has imposed domestic and international travel restrictions. Some countries have imposed arrival and departure restrictions for foreigners. International flights are restricted, and some countries have issued flight bans to some countries. Flights within the network are vulnerable to the spread of international infections through air. If the government imposes partial restrictions on air travel, the closure of highly operated airports has the potential to slow (but not stop) the virus transmission more effectively than total restrictions on international air travel. However, this heterogeneity only has a significant role when numbers of global cases are low. Once there are thousands of cases and multiple epidemics, travel restrictions have a slight impact even if optimally targeted (Hollingsworth, 2006).

Restrictions on air transportation in Indonesia began on May 8, 2020. Air travel can still be done as long as the passangers complete several health documents such as the rapid test and polymerase chain reaction (PCR) test results, which were deemed hostile. Airplane passengers must meet the requirements by showing a negative result of the RT-PCR test (the sample is taken in a maximum of $3 \times 24$ hours before departure) or a negative result of the rapid antigen test (the sample is taken in a maximum of $2 \mathrm{x}$ 24 hours before departure) for flights from and to areas other than Bali Island (tirto, 2021).

Travel restrictions are also the results of lockdown applied in several cities and countries. Studies suggested that the late lockdown decisions in the US costed approximately 36,000 more lives (New York Times, 2020). Thus, lockdown and social distancing rules appear to be the most effective way to contain the COVID-19 domestically and globally (Chinazzi et al., 2020; Lau et al., 2020; Zhang et al., 2020b).

\section{Method}

This study was conducted in Surabaya as the capital of the East Java province which has implemented large-scale restrictions (LSSR). This policy had affected people's intention to travel. This study used opportunistic sampling to select all available individuals with given characteristics for inclusion in the sample (Zikmund, 2002).

The data of this study were collected in several ways. Data could be documents and infographics. A literature study was done by studying journals, articles, and other reports related to the research. The author then compressed the data to simplify and clarify the results and to understand the final results quickly. The next stage was data presentation where the data were then presented visually through a pie chart.

The data were collected by distributing a Google form questionnaire link. The questionnaire was designed only to determine the intention of Surabaya people in taking a trip during the pandemic. It was distributed from June 2020 to October 2020 on social media, including WhatsApp, Instagram, and Facebook. A total of 500 questionnaires were distributed, but only 121 questionnaires met the criteria and could be used. A total of 121 respondents from Surabaya answered the questionnaires and met the inclusion criteria. The distributed questionnaires contained questions to collect the primary data and supporting information.

The questions asked to the respondents included demographics, namely gender, age range, and occupation. Then the next question referred to the intention of Surabaya people to travel during the pandemic. Besides, the last question asked was about which tourism destination people miss the most and want to visit after the pandemic subsides. The respondents were given freedom to choose several 
choices between marine tourism, green tourism, culinary tourism, and religious tourism available as recreational tourism in Surabaya.

\section{Results}

Of 121 respondents who participated in this study, 39 respondents were interested in traveling during the pandemic, while 82 others had no interest to travel.

Table 1. Respondents' answers about their intention to travel during the pandemic

\begin{tabular}{ccc}
\hline Intention & $\begin{array}{c}\text { Frequency } \\
\text { (people) }\end{array}$ & Percentage (\%) \\
\hline Interested & 39 & $32 \%$ \\
Not Interested & 82 & $68 \%$ \\
\hline
\end{tabular}

Table 2. Respondents' answers about their intention to travel during after the pandemic

\begin{tabular}{ll}
\hline Destinations & $\begin{array}{l}\text { Frequency } \\
\text { (answers) }\end{array}$ \\
\hline Green Tourism & 106 \\
Culinary Tour & 54 \\
Marine Tourism & 29 \\
Religious Tourism & 14 \\
\hline
\end{tabular}

Green tourism was mentioned 106 times to be a destination they wanted to visit after the pandemic. The third most chosen destination was culinary tourism mentioned 54 times. Marine tourism was mentioned 29 times and ranked the second most visited one after the pandemic. Lastly, religious tourism was mentioned 14 times by the respondents.

\section{Discussion}

The Covid-19 first appeared in Wuhan on December 31, 2019. The World Health Organization (WHO) announced that a similar outbreak occurred in Thailand, South Korea, and Japan on January 20, 2020. Countries in Asia and other parts of the world have also reported similar cases. Indonesia announced its first Covid-19 case on March 2, 2020 and on March 11, 2020. The WHO announced that Covid-19 was a pandemic because it had surpassed the SARS epidemic case in 2003, sequentially several countries imposed lockdowns and travel restrictions. Similar to Indonesia, when the number of Covid-19 cases increased, Jokowi President decided to implement a lockdown and LSSR in various cities.

With the implementation of lockdown in Indonesia and LSSR in various cities, several activities where large numbers of people gather were stopped or be temporarily postponed to prevent the spread of this virus. The world of tourism has undoubtedly faced the impact of this pandemic. Several tourist destinations were temporarily closed at an indefinite time. The Provincial Government of DKI Jakarta represented by the Head of the DKI Jakarta Tourism and Creative Economy Office, 2020 issued a circular letter No. 155/SE/2020, 160/SE/2020, and 184/SE/2020 concerning the Temporary Closure of the Tourism Industry Operational Activities, starting from March 20 to April 2, March 20 - April 5, 2020, and 6-19 April 2020 (Soehardi 2020). Also, some tourists who had already been planning on 
vacation were required to cancel their tickets. All of these policies, of course, reduced the percentage of tourists during the pandemic in 2020.

Followed by the decision to close tourism temporarily, the Indonesian Ministry of Health issued a decree No. HK.01.07/MENKES/382/2020 concerning Health Protocols for Communities in Public Places and Facilities in the Context of Prevention and Control of Corona Virus Disease 2019 (Covid19). The decree was enacted and came into effect on June 19,2020. The decision should be followed by all people doing activities at home or outside to prevent and minimize the spread of the covid- 19 .

Travel restrictions have also caused reduced foreign exchange earnings. Apart from reducing state income, the Covid-19 pandemic also sluggishes the tourism sector. In addition to the international travel restrictions, several countries have also imposed restrictions on domestic travel. Even the social distancing campaign that has turned into physical distancing, where each individual is expected to maintain a safe distance limit between each other to contain Covid-19.

During the pandemic, people have less intensity to travel. People are forced to postpone their planned tour. The spread of the virus, which is rapid in Indonesia, has prompted the government to close several tourist attractions to prevent crowds. Based on the news published in Kompas.com (2020), it was noted that at least ten tourist attractions in East Java began to be closed temporarily as of March 15, 2020, while 46 others were closed as well on the following dates. Ivanova (2020) found that the primary motivation to travel is for having relaxation (46.1\%), which differs form any other conventional reasons (Ivanova, 2020); this study goes in line with the preferences of Indonesians, who search for more green holidays (Wachyuni \& Kusumaningrum, 2020). Previous significant research also found that a factor that helps understand seniors' travel is motivation as the key driving force behind travel behavior (Crompton, 1979). According to the age group, senior baby boomers were expected to be more critical as having more purchasing power (Jang, 2009).

Less intention to travel does not make people lose their desire to visit tourism destinations. The respondents chose green tourism that they missed most. Green tourism is necessary to understand tourist behaviors and apply specific rules. It is also a strategy for entertaining or serving tourists (Novianti, 2020). Compared to tourism destinations with other concepts, green tourism has a significant and impactful added value experience for tourists (Novianti, 2020). It also promotes people's health while they visit it. Inbuilt environments, trees, and landscaping may improve health not only because of the positivity, for instance, from phytoncides that can reduce negative aspects such as air pollution associated with myocardial inflammation and respiratory conditions (Villarreal-Calderon et al., 2012). This review revealed a multiplicity of mechanisms by which contact with nature might promote health, as well as a promise candidates for a central pathway (Kuo,2015).

Marine and coastal tourism including sea activities is also growing fast and vital for the economy. Marine tourism activities take place on sea while supporting facilities and infrastructure are usually found on land. Contrary to marine tourism activities attractive to municipalities and urban environments, facilities related to coastal tourism usually attractive are the coastal natural landscape, where estuaries, wetlands, coral reefs, and other fragile components of the ecosystem nature are encountered (Dimas, 2018). Maritime tourism is the government's concern in developing tourism in Indonesia and being included in the 10 new Bali. The government has also developed marine tourism programs in coastal areas other than Bali, which are expected to become a destination for foreign and domestic tourists. Therefore, it is necessary to carry out further research regarding the impact of the Covid-19 pandemic on various tourism sectors. It will be related to post-plague recovery and able to assist the Indonesian government in restoring the tourism sector, especially in the 10 main areas of new Bali such as Mandalika, Borobudur, Bromo, Tanjung Lesung, Wakatobi, Labuan Bajo, Moratai, Lake Toba, Seribu Island, and Belitung Island. 
Culinary tourism, which is famously called gastronomy tourism, has become an essential aspect of tourism to attract international tourists (Horng \& Tsai, 2010). Many destinations use food as a source of attraction in their marketing (Lin, Pearson \& Chai, 2011). Gastronomy tourism has positive impacts on the economy and the tourism environment, as well as increases the sustainability of the region (Everett \& Aitchison, 2008). Culinary as a souvenir would increase the effect of the whole traveling experience (cf. Horng \& Tsai, 2010).

Another tourism destination mentioned by the respondents was religious tourism that includes various activities such as pilgrimages, missionary trips, monasteries or convent retreats, religious camps or events, conferences, and religious meetings (CBI, 2016). Rejman (2016), in his article, explained that the present religious travel such as pilgrimage has become an essential phenomenon of the religious, cognitive, cultural, and socio-economic aspects. Religious tourism still became a choice for some people of Surabaya to do after the pandemic has subsided. Religious Tourism is all kinds of tourism, instilled with the ethical value of Islam served for all (Sofyan, 54: 2012). Islamic tourism includes all types of tourism added with Islamic values, which everyone enjoys (Madyan, 2015). Muslim tourists are a new segment that is overgrowing in the tourism industry. Muslim tourists continue to travel but do not sacrifice their basic needs, for example, being selective for halal food and easy to carry out worship (Madyan, 2015). The progress of religious tourism also requires the support from the local government and the community; consequently, religious tourism in certain areas can develop more rapidly and grow the economy of the surrounding community. This finding is in line with previous research that suggested the residents' support for religious tourism development in Santa Cruz, RN was influenced significantly by the perceived benefits of tourism and trust in government actors (Silva, 2016).

This study only covers the Surabaya areas. Further research is expected to use a broader population and samples, as well as deepen and sharpen the questions asked to obtain more holistic results.

\section{Conclusions}

During the pandemic, people have obeyed and complied with government regulations to stay away from public places and not to travel. Apart from the significant spread of Covid-19, the government closed several tourist attractions and imposed large-scale social restrictions.

People still wanted to travel after the pandemic has subsided. Green tourism is a tourist spot in an open area that makes people enjoy the beauty of open nature. This attraction can make them healthier and have less pollution.

Culinary tourism was also the destination chosen by the respondents to visit after the pandemic has subsided. Indonesia, which is rich in Indonesian culinary delights, can be an attraction for the community. Traditional Indonesian herbal medicine, recommended for consumption during the pandemic, is believed to increase people's immunity with regular consumption and dosage. Doctor Ina stated that traditional medicine in the Covid-19 pandemic was beneficial to increase endurance or to complement conventional drugs given to Covid-19 patients, thereby increasing one's immune system (fk.ugm.ac.id, 2020).

Marine tourism was one of the alternative tourist destinations that the respondents want to visit after the pandemic has subsided. It involves the beach and sea attractions such as water sports. Furthermore, it also manages the provision of commercial facilities and infrastructure and other services in coastal areas, beaches, rivers, lakes, and reservoirs (Halim et al., 2017).

Observing the community's enthusiasm in choosing several tourist destinations mentioned above, the tourism sector, especially in Indonesia, has potential recovery. The pandemic forced tourism destination to be closed, but it did not last long due to the 'new normal' in August and the CHSE (Cleanliness, Health, Safety, and Environmental Sustainability) implemented in Indonesia. The Language 
Development Agency of the Indonesian Ministry of Education and Culture uses the term "new normal" equivalent to the term "new normal", which refers to the new normal state (Adit, 2020). In August 2020, the Indonesian Minister of Tourism and Creative Economy issued health protocols guidelines for tourism to be implemented amids the pandemic. Previous few months had been the most challenging period experienced by the world of tourism, which were required to close their tours. Broadly speaking, the CHSE in Indonesia requires the tourism providers to provide a sink, measure temperature, maintain distance, warn tourists to use masks according to the health index, and place disinfectants in every spot (Ministry of Tourism and Creative Economics/Creative Economic and Tourism Agency 2020). Not only that, tour providers also have to clean tourist attractions at all times. With the existence of several health protocols, tourists will be interested to travel and feel comfortable with the cleanliness of the tourist attractions. That way, tourist statistics in August and after that would be expected to grow and preserve the sustainability of tourism in Indonesia.

With the latest health protocol guidelines for tourism, people start to plan another vacation after staying at home for months although they might feel worried about the health safety. For this reason, tourism providers and other stakeholders who understand the health protocols for tourism need to educate the community about what to do and bring when they visit tourist attractions. They also need to understand what must be prepared and provided in the tour.

\section{Acknowledgments}

The authors thanked the Airlangga University Research and Innovation Institute for funding this study.

\section{References}

Abdul Halim, B. W. (2017). Konsep hak pengelolaan perikanan sebagai alat pengelolaan. Jurnalkebijakanperikananindonesia (9), 11-20.

Adit, A. (2020). Ini Padanan Kata "New Normal" dari Badan Bahasa Kemendikbud. Retrieved from Kompas.com: https://edukasi.kompas.com/komentar/2020/05/26/152138171/inipadanan-kata-new-normal-dari-badan-bahasa-kemendikbud

Adit, A. (2020). Kompas.com. from https://edukasi.kompas.com/komentar/2020/05/26/152138171/ini-padanan-kata-newnormal-dari-badan-bahasa-kemendikbud

Astuti, Y. (2020). Syarat Beli Tiket Pesawat: Wajib Rapid Test Covid-19! Retrieved from CNBC Indonesia: 6. https://www.cnbcindonesia.com/news/20200521120059-4160057/syarat-beli-tiket-pesawat-wajib-rapid-test-covid-19

Bangga Surabaya News. (2020). BanggaSurabaya.com. Retrieved from Akses Masuk ke Surabaya Tak Ditutup, Hanya Dibatasi Pergerakannya: https://humas.surabaya.go.id/2020/04/05/akses-masuk-ke-surabaya-tak-ditutup-hanyadibatasi-pergerakannya/

Billy Bai, C. H. (2009). Affect, Travel Motivation, and Travel Intention: a Senior Market. Journal of Hospitality \& Tourism Research 33(1), 51-73.

BPS JAWA TIMUR. (2020). Jumlah Wisman ke Jawa Timur melalui pintu masuk Juanda bulan Maret turun sebesar 50,65 persen sedangkan TPK hotel berbintang turun sebesar 15,84 poin. Retrieved from Badan Pusat Statistik Provinsi Jawa Timur: 
https://jatim.bps.go.id/pressrelease/2020/05/04/1114/jumlah-wisman-ke-jawa-timurmelalui-pintu-masuk-juanda-bulan-maret-turun-sebesar-50-65-persen-sedangkan-tpkhotel-berbintang-turun-sebesar-15-84-poin.html

Cahyani, I. A. (2020). UPDATE Kasus Corona di Jawa Timur 19 April 2020: Total 590 Kasus Positif, 98 Sembuh, 54 Meninggal. Retrieved from Tribunnews.com: https://www.tribunnews.com/regional/2020/04/19/update-kasus-corona-di-jawa-timur19-april-2020-total-590-kasus-positif-98-sembuh-54-meninggal

CBI. (2020). The European market potential for religious tourism. Retrieved from cbi.eu: https://www.cbi.eu/market-information/tourism/religious-tourism/.

Dimas Tegar, R. O. (2018). Development of Marine and Coastal Tourism Based on Blue Economy. International Journal of Marine Engineering Innovation and Research, 2(2), 128-132.

Evi Novianti, A. R. (2020). Pariwisata Berbasis Alam: Memahami Perilaku Wisatawan. Jurnal Kepariwisataan Indonesia: Jurnal Penelitian Dan Pengembangan Kepariwisataan Indonesia, 14(1), 46-52.

Fakultas Kedokteran, Kesehatan Masyarakat dan Keperawatan. (2020). Obat Tradisional di Era Pandemi Covid-19. Retrieved from fk.ugm.ac.id: https://fk.ugm.ac.id/obattradisional-di-era-pandemi-covid-19/

Hakim, R. N. (2020). Disetujui Menkes, PSBB DKI Jakarta Mulai Berlaku Selasa 7 April 2020. Retrieved from

Kompas.com: https://nasional.kompas.com/read/2020/04/07/11582841/disetujui-menkes-psbb-dkijakarta-mulai-berlaku-selasa-7-april2020?page=all\#: :text=Surat\%20Kepmenkes\%20itu\%20ditetapkan\%20di\%20Jakarta $\%$ 20pada\%20Selasa\%2C\%207\%20April\%202020.\&text=Artinya\%2C\%20PSBB\%20 d

Hien Lau, e. a. (2020). The positive impact of lockdown in Wuhan on containing the COVID19 outbreak in China. Journal of Travel Medicine vol 277, 1-7.

Horng, J.-S. (2010). Government Websites for Promoting East Asian Culinary Tourism: A Cross-National Analysis. Tourism Management 31(1), 74-85.

Idhom, A. M. (2021). Syarat Naik Pesawat Bulan Februari 2021 \& Aturan Perjalanan Terbaru. Retrieved from Tirto.id: https://tirto.id/syarat-naik-pesawat-bulan-februari2021-aturan-perjalanan-terbaru-gabN

James Glanz, C. R. (2020). Lockdown delays cost at least 36,000 lives, data show. Retrieved from NewYorkTimes.com: https://www.nytimes.com/2020/05/20/us/coronavirusdistancing-deaths.html

Krzysztof Rejman, P. M. (2016). Religious Tourism As A Tourism Product. World Scientific News 57, 562-575.

L.Crompton, J. (1979). Motivations for pleasure vacation. Annals of Tourism Research 6, 408424.

Leggett, T. (2020). Dampak virus corona pada industri penerbangan: Kapankah maskapai, 'pusat saraf bisnis dan wisata internasional', akan kembali beroperasi seperti sediakala? Retrieved from BBC NEWS: https://www.bbc.com/indonesia/dunia52577423 
M.Lopez, A. (2020). Change in consumer expenditure due to the coronavirus (COVID-19) pandemic in Brazil in April 2020, by selected categories. Retrieved from Statista.com: https://www.statista.com/statistics/1113083/consumer-spending-change- coronavirusbrazil/.

Matteo Chinazzi, e. a. (2020). The effect of travel restrictions on the spread of the 2019 novel coronavirus (COVID-19) outbreak. Science, 1-11.

Maya Ivanova, v. K. (2020). Travel behaviour after the pandemic: the case of Bulgaria. An international journal of tourism and hospitality research , 1-16.

Medistiara, Y. (2020). Menkes Setujui PSBB di Surabaya, Sidoarjo, dan Gresik. Retrieved from Detiknews.com: https://news.detik.com/berita/d-4985262/menkes-setujui-psbb-disurabaya-sidoarjo-dan-gresik

OpenTable. (2021). The state of the restaurant industry. Retrieved from OpenTable.com: http://www.opent able.com/state-of-industry

Peregrine, P. (2008). Sampling Theory. Lawrence University and the Santa Fe Institute, 1-3.

Ramadhian, N. (2020). 56 Tempat Wisata di Jawa Timur yang Tutup, Cegah Penyebaran Virus Corona. Retrieved from $\quad 7$. https://travel.kompas.com/read/2020/03/20/200100427/56-tempat-wisata-di-jawatimur-yang-tutup-cegah-penyebaran-virus-corona?page=all

Richter, F. (2020). The Pandemic's Toll on the U.S. Restaurant Industry. Retrieved from Statista.com: https://www.statista.com/chart/23765/impact-of-the-covid-19-pandemico n-the-us-restaurant-industry/.

Ristyawati, A. (2020). Efektifitas Kebijakan Pembatasan Sosial Berskala Besar Dalam Masa Pandemi Corona Virus 2019 oleh Pemerintah Sesuai Amanat UUD NRI Tahun 1945. Administrative Law and Governance Journal, 1-10.

Sally Everett, C. A. (2008). The Role of Food Tourism in Sustaining Regional Identity: A Case Study of Cornwall, South West England. Journal of Sustainable Tourism 16(2), 150167.

Soehardi Seohardi, D. A. (2020). Pengaruh Pandemik Covid-19 Terhadap Pendapatan Tempat Wisata dan Kinerja Karyawan Pariwisata di Jakarta. Jurnal Kajian Ilmiah 1 (1), 1-14.

Suci Sandi Wachyuni, D. A. (2020). The Effect of COVID-19 Pandemic: How . Journal of Education, Society and Behavioural Science, 33(4), 67-76.

Sugiyono, P. D. (2008). Metode penelitian pendidikan:(pendekatan kuantitatif, kualitatif dan $R$ \& D). Bandung: Alf.

T. Deirdre Hollingsworth, N. F. (2006). Will travel restrictions control the International spread of pandemic influenza? Nature Medicine 12(5), 497-499.

Tureac, C. (2008). Types of Forms of Tourism. Ceconomica, 92-103.

Yahua Zhang, A. Z. (2020). Exploring the roles of high-speed train, air and coach services in the spread of COVID-19 in China. Transport Policy 94.

Yi Chin Lin, T. E. (2011). Food as a Form of Destination Identity: A Tourism Destination Brand Perspective. Tourism and Hospitality Research, 11(1), 30 - 48. 


\title{
Minat Masyarakat Mengunjungi Destinasi Wisata Semasa Pandemi COVID-19 Di Surabaya
}

\begin{abstract}
Abstrak
Pariwisata sangat terpengaruh oleh pandemi yang mengakibatkan pembatasan sosial dan pembatasan perjalanan. Menurunnya jumlah wisatawan yang berkunjung untuk berwisata tidak hanya berdampak pada kota wisata, tetapi juga berdampak pada Surabaya. Makalah ini bertujuan untuk menganalisis keinginan masyarakat Surabaya untuk berwisata saat terjadi pandemi. Sebanyak 121 responden berasal dari masyarakat yang berdomisili di Surabaya setuju untuk mengikuti kuesioner. Hasil temuan menunjukkan bahwa mayoritas masyarakat Surabaya tidak berniat berwisata selama pandemi. Hal ini dikarenakan masyarakat Surabaya mendapatkan banyak sekali pembatasan perjalanan, diantaranya pembatasan sosial berskala besar yang sudah beberapa kali diterapkan di Kota Surabaya. Pembatasan perjalanan tersebut tidak hanya mengurangi kesempatan masyarakat Surabaya untuk bepergian ke luar wilayah Surabaya tetapi juga membatasi perjalanan penduduk di luar Surabaya yang akan berkunjung. Hasil kuesioner menunjukkan bahwa wisata alam merupakan tujuan wisata yang paling banyak dipilih oleh responden sebagai destinasi wisata yang ingin responden kunjungi setelah pandemic mereda. Dilanjutkan dengan wisata kuliner kemudian wisata bahari dan wisata religi sebagai pilihan keempat sebagai tempat wisata yang ingin dikunjungi setelah pandemic mereda. Saran yang dapat diberikan untuk penelitian selanjutnya adalah agar pemerintah dapat memberikan penyuluhan yang lebih masif mengenai pentingnya menjaga kebersihan, misalnya dengan mengganti masker secara berkala, dan memberikan edukasi kepada masyarakat bahwa penerapan Cleanliness Health Environment and Safety (CHSE) adalah sangat penting untuk diterapkan oleh semua pelaku pariwisata, destinasi wisata dan tempat umum lainnya. Serta minimnya penelitian tentang niat masyarakat Indonesia dalam berwisata pasca pandemi harus ditingkatkan ke depannya.
\end{abstract}

Kata Kunci: pariwisata, minat, CHSE 